\title{
Analisis Kinerja Belanja Pemerintah daerah Kotamobagu dan Bolaang Mongondow Timur tahun 2009-2012
}

\author{
Herman Karamoy \\ (hkaramoy@yahoo.com) \\ Heince Wokas \\ (heince_wokas@yahoo.com)
}

\begin{abstract}
Budget Realization Report (LRA) which published local governments provide very useful information to assess the financial performance. This study aims to analyze the performance of the Local Government and Bolaang Mongondow Timur dan Kotamobagu 2009-2012. The analysis showed that both the local government needs to improve the performance of the financial management
\end{abstract}

Laporan Realisasi Anggaran (LRA) yang dipublikasikan pemerintah daerah memberikan informasi yang sangat bermanfaat untuk menilai kinerja keuangan daerah penelitian ini bertujuan untuk menganalisis kinerja Pemerintah Daerah Kota Kotamobagu dan Kabupaten Bolaang Mongondow Timur tahun 2009-2012. Hasil analisis menunjukkan bahwa kedua Pemda perlu meningkatkan kinerja dalam pengelolaan keuangan.

\section{A. Pendahuluan}

Kemampuan pemerintah daerah dalam mengelola keuangannya dituangkan dalam APBD yang menggambarkan kemampuan pemerintah daerah dalam membiayai kegiatannya. Anggaran Pendapatan dan Belanja Daerah merupakan salah satu isntrumen kebijakan utama bagi pemerintah daerah.

Dalam konteks pengelolaan keuangan daerah, anggaran belanja sangat berkaitan dengan perencanaan keuangan jangka panjang, terutama pembiayaan untuk pemeliharaan aset tetap yang dihasilkan dari belanja modal. Konsep Multi-Term Expenditure Framework (MTEF) menyatakan bahwa kebijakan belanja harus memperhatikan kemanfaatan (usefulness) dan kemampuan keuangan pemerintah daerah (budget capability) (Allen dan Tommasi, 2001).

Pengelolaan keuangan daerah tergambar dalam laporan keuangan yang dihasilkan oleh setiap pemerintah daerah. Laporan keuangan merupakan informasi yang penting karena dari laporan keuangan inilah dapat diketahui kinerja dari suatu pemerintah daerah. Kinerja adalah ukuran keberhasilan dari setiap kegiatan operasional organisasi. Salah satu alternatif untuk mengetahui informasi keuangan yang dihasilkan bermanfaat untuk memprediksi kinerja, dengan dilakukan analisis rasio keuangan. Menurut Penman (1991:48) seperangkat laporan keuangan utama belum dapat memberikan manfaat maksimal bagi pemakai sebelum pemakai menganalisis laporan keuangan tersebut dalam bentuk rasio keuangan.

Laporan Realisasi Anggaran (LRA) yang dipublikasikan pemerintah daerah memberikan informasi yang sangat bermanfaat untuk menilai kinerja keuangan daerah (Mardiasmo 2002). LRA menjadi salah satu laporan pertanggungjawaban keuangan daerah yang utama, karena berdasarkan LRA tersebut pengguna laporan dapat membuat analisis kinerja keuangan berupa analisis pendapatan, analisis belanja dan analisis pembiayaan. 


\section{B. Tinjauan Pustaka}

Peraturan Pemerintah Republik Indonesia Nomor 105 Tahun 2000 tentang Pengelolaan dan Pertanggungjawaban Keuangan Daerah, menyebutkan bahwa yang dimaksud keuangan daerah adalah semua hak dan kewajiban daerah dalam rangka penyelenggaraan pemerintah daerah yang dapat dinilai dengan uang termasuk didalamnya segala bentuk kekayaan daerah tersebut, dalam kerangka Anggaran, Pendapatan dan Belanja Daerah. Selanjutnya dalam pasal 4 dan 5 dikatakan pula bahwa pengelolaan keuangan daerah dilakukan secara tertib, taat pada peraturan perundang-undangan yang berlaku, efisien, efektif, transparan dan bertanggung jawab dengan memperhatikan azas keadilan dan kepatuhan sehingga Anggaran Pendapatan dan Belanja Daerah merupakan dasar pengelolaan keuangan daerah dalam tahun anggaran tertentu. Menurut Devas, dkk (2000:279-280), Pengelolaan keuangan daerah berarti mengurus dan mengatur keuangan daerah itu berdasarkan pada prinsip-prinsip.

Peraturan Pemerintah Republik Indonesia Nomor 58 Tahun 2005 tentang Pengelolaan Keuangan Daerah khususnya dalam Bab XV yang menyatakan tentang Peraturan Pengelolaan Keuangan Daerah menekankan bahwa :

1. Ketentuan tentang pokok-pokok pengelolaan keuangan daerah diatur dengan peraturan daerah sesuai dengan ketentuan peraturan perundang-undangan.

2. Berdasarkan peraturan daerah sebagaimana dimaksud pada ayat (1), kepala daerah menetapkan peraturan daerah tentang sistem dan prosedur pengelolaan keuangan daerah.

Dalam Peraturan Pemerintah Nomor 24 Tahun 2005 tentang Standar Akuntansi Pemerintahan pada Pernyataan Nomor 02 mengemukakan bahwa tujuan Laporan Realisasi Anggaran diantaranya :

a. Tujuan standar Laporan Realisasi Anggaran adalah menetapkan dasar-dasar penyajian Laporan Realisasi Anggaran Pemerintah dalam rangka memenuhi tujuan sebagaimana ditetapkan oleh peraturan perundang-undangan.

b. Tujuan pelaporan realisasi anggaran adalah memberikan informasi tentang realisasi dan anggaran entitas pelaporan secara tersanding. Penyandingan antara anggaran dan realisasinya menunjukkan tingkat ketercapaian target-target yang telah disepakati antara legislatif dan eksekutif sesuai dengan peraturan perundang-undangan.

Laporan Realisasi Anggaran dapat menyediakan informasi kepada para pengguna laporan tentang indikasi perolehan dan penggunaan sumber daya ekonomi :

1) Telah dilaksanakan secara efisien,efektif dan hemat;

2) Telah dilaksanakan sesuai dengan anggarannya (APBN/APBD);

3) Telah dilaksanakan sesuai dengan peraturan perundang-undangan.

Mahmudi (2006:141) mengemukakan definisi belanja berdasarkan Standar Akuntansi Keuangan Pemerintahan, belanja daerah dapat didefinisikan sebagai berikut : "Semua pengeluaran dari Rekening Kas Umum Daerah yang mengurangi ekuitas dana lancar dalam periode tahun anggaran yang bersangkutan yang tidak akan diperoleh pembayarannya kembali oleh pemerintah daerah". Selanjutnya Halim (2004:74) mengemukakan definisi belanja adalah penurunan aktiva dan atau kenaikan utang yang digunakan untuk berbagai kegiatan dalam satu periode akuntansi.

Jadi Belanja dapat dipahami sebagai kewajiban pemerintah daerah yang mengurangi kekayaan bersih yang akan terjadi akibat transaksi masa lalu. Namun dalam hal ini perlu dipahami bahwa belanja daerah berbeda dengan pengeluaran daerah. Tidak semua 
pengeluaran yang dilakukan pemerintah daerah yang menyebabkan berkurangnya kas di rekening Kas Umum Daerah dikategorikan sebagai belanja.

Belanja diakui dalam periode berjalan dan pada akhir periode akuntansi (Permendagri 13 thn 2006). Pengakuan belanja non modal/investasi dalam periode berjalan berdasarkan jumlah kas yang dikeluarkan. Pada akhir periode akuntansi, belanja non modal diakui berdasarkan jumlah belanja non modal yang sampai akhir periode akuntansi telah menjadi kewajiban tetapi belum ada realisasi pengeluaran kas. Belanja modal diakui dalam periode berjalan pada saat aktiva yang dibeli telah diterima dan hak kepemilikannya telah berpindah. Kontrol atas pengeluaran belanja (penerimaan kembali belanja) yang terjadi pada periode berjalan dicatat sebagai pengurangan belanja. Apabila diterima pada periode berikutnya dicatat dalam Lain-lain Pendapatan Asli Daerah yang Sah.

Pengukuran belanja non modal menggunakan mata uang rupiah berdasarkan nilai sekarang kas yang dikeluarkan dan atas akun dikeluarkan. Pengukuran belanja modal menggunakan dasar yang digunakan dalam pengukuran aktiva tetap. Belanja yang diukur dengan mata uang asing dikonversi ke mata uang rupiah berdasarkan nilai tukar (kurs tengah Bank Indonesia) pada saat pengakuan belanja.

\section{Metode Penelitian}

Penelitian ini menggunakan data sekunder berupa Laporan Realisasi Anggaran tahun 2009 sampai tahun 2012 yang diperoleh dari Pemerintah Kota Kotamobagu dan Kabupaten Bolaang Mongondow Timur. Metode analisis dalam penelitian ini adalah dengan menggunakan metode analisis deskriptif. yang menguraikan hasil analisis dari belanja serta bagaimananya kinerjanya terhadap LRA. jenis analisis yang akan dilakukan adalah sebagai berikut :

a) Analisis Varians Belanja

b) Analisis Pertumbuhan Belanja

Pertumbuhan Belanja Tahun $_{t}=\underline{\text { Realisasi Belanja Tahun }}{ }_{t}-$ Realisasi Belanja Tahun $_{t-1}$

c) Analisis Keserasian Belanja

$$
\text { Realisasi Belanja Tahun } \text { t-1 }_{1}
$$

Analisis keserasian belanja antara lain berupa :

1) Analisis Belanja Operasi terhadap Total Belanja

Rasio Belanja Operasi terhadap Total Belanja $=\underline{\text { Total Belanja Operasi }}$

Total Belanja Daerah

2) Analisis Belanja Modal terhadap Total Belanja

Rasio Belanja Modal terhadap Total Belanja $=\underline{\text { Realisasi Belanja Modal }}$

Total Belanja Daerah

d) Rasio Efisiensi Belanja, dengan rumus

Rasio Efisiensi Belanja $=\underline{\text { Realisasi Belanja } \times 100 \%}$

Anggaran Belanja

\section{Hasil dan Pembahasan}

Berdasarkan hasil analisis varians belanja tahun anggaran 2009-2012 (lihat Lampiran), laporan keuangan Pemerintah Kota Kotamobagu realisasi belanja lebih kecil dari 
anggarannya maka dapat disimpulkan terjadi selisih kurang yang disebut favourable variance. Namun setiap tahun sejak Tahun Anggaran 2009 hingga 2011 selisih kurang yang terjadi nilainya sangat besar (baik secara nominal maupun prosentase) dan memiliki trend selalu naik setiap tahunnya. Hal ini dapat menunjukkan adanya kelemahan dalam perencanaan anggaran Pemerintah Kota Kotamobagu sehingga estimasi belanjanya kurang tepat. Tetapi pada tahun 2012 selisih ini berkurang dan artinya Pemda kotamobagu mulai memperbaiki kelemahan tersebut.

Untuk Pemerintah Kabupaten Bolaang Mongondow Timur, jika dilihat dari data hasil analisis bahwa realisasi belanja lebih kecil dari anggarannya maka dapat disimpulkan terjadi selisih kurang yang disebut favourable variance. Namun untuk Tahun Anggaran 2010 sampai 2011, selisih kurang yang terjadi nilainya sangat besar (baik secara nominal maupun prosentase) dan baru bisa berkurang pada Tahun Anggaran 2012. Hal ini menunjukkan adanya kelemahan dalam perencanaan anggaran Pemerintah Daerah Bolaang Mongondow Timur sehingga estimasi belanjanya kurang tepat, terutama untuk penganggaran Pos Belanja Barang serta Pos Belanja Gedung dan Bangunan, dimana dua jenis belanja tersebut, masingmasing pada Tahun Anggaran 2009 hingga 2012 merupakan penyumbang utama terjadinya favourable variance yang sangat besar.

D.1. Analisis Pertumbuhan Belanja

Dari hasil analisis pertumbuhan belanja tahun anggaran 2009-2010, diketahui dari data Pemerintah Kota Kotamobagu bahwa pertumbuhan belanja untuk Tahun Anggaran 2009/2010 adalah sebesar Rp75.980.790.445,00 atau 26,55\%. Kenaikan terbesar disumbangkan oleh Pos Belanja Pegawai sebesar Rp36.055.282.675,00 atau 47,45\% dari jumlah kenaikan belanja dan Pos Belanja Gedung dan Bangunan sebesar Rp22.079.537.090,00 atau 29,05\% dari jumlah belanja sebelumnya. Kenaikan tersebut disebabkan adanya penambahan jumlah pegawai dalam jumlah besar dan banyak melakukan pembangunan gedung sehingga berimbas pada meningkatnya Belanja Pegawai dan Belanja Gedung dan Bangunan. Sementara itu, diketahui pertumbuhan belanja untuk Tahun Anggaran 2010/2011 adalah sebesar Rp18.430.530.043,00 atau 5,09\%. Kenaikan terbesar disumbangkan oleh Pos Belanja Pegawai sebesar Rp34.529.861.243,00 dan Belanja Barang sebesar Rp15.963.839.257,00. Kenaikan tersebut disebabkan adanya penambahan jumlah pegawai dalam jumlah besar dan meningkatnya kebutuhan barang habis pakai sehingga berimbas pada meningkatnya Belanja Pegawai dan Belanja Barang. Namun di sisi lain, juga terdapat penurunan belanja yang cukup signifikan pada Pos Belanja Gedung dan Bangunan sebesar Rp21.424.752.985,00 serta Pos Belanja Jalan, Irigasi dan Jaringan sebesar Rp18.029.269.333,00. Hal ini menunjukkan pembangunan infrastruktur yang dilakukan tidak sebanyak tahun sebelumnya. Untuk tahun anggaran 2011/2012 terjadi penurunan belanja dari tahun sebelumnya namun karena adanya penambahan pegawai dan naiknya gaji dan tunjangan maka pos belanja pegawai naik sebesar 12,68\%

Untuk Pemerintah Kabupaten Bolaang Mongondow Timur diketahui pertumbuhan belanja untuk Tahun Anggaran 2009/2010 adalah sebesar Rp. 171,465,731,706.00 atau 253,5\%. Kenaikan terbesar disumbangkan oleh Pos Belanja Gaji sebesar Rp. 35,265,865,733.00 atau 84,73\% dari jumlah kenaikan belanja dan Pos Belanja Jalan, Irigasi dan Jaringan sebesar Rp. 68,464,325,990.00 atau 6.336\% dari jumlah belanja sebelumnya. Kenaikan tersebut menunjukkan penambahan pegawai karena kebutuhan pada kabupaten pemekaran dan naiknya tunjangan pegawai serta pembangunan infrastruktur jalan, irigasi dan jaringan sehingga berimbas pada meningkatnya Belanja Barang dan Belanja Jalan, Irigasi, dan Jaringan. Sementara itu, pertumbuhan belanja untuk Tahun Anggaran 2010/2011 diketahui sebesar Rp. 107,862,129,500.00 atau 45,11\%. Kenaikan terbesar disumbangkan oleh Pos Belanja Pegawai sebesar Rp.29.440.512.253,00 atau 38,29\% dari jumlah kenaikan belanja dan Pos Belanja Gedung dan Bangunan sebesar Rp.27.690.677.291,00 atau 121.99\% 
dari jumlah belanja sebelumnya. Kenaikan tersebut disebabkan adanya penambahan jumlah pegawai dalam jumlah besar serta banyak melakukan pembangunan gedung sehingga berimbas serta pada meningkatnya Belanja Pegawai dan Belanja Gedung dan Bangunan.

\section{D.2. Analisis Keserasian Belanja}

Dari hasil analisis keserasian belanja tahun anggaran 2009-2011, data Pemerintah Kota Kotamobagu menujukkan analisis belanja operasi terhadap total belanja pada Pemerintah Kota Kotamobagu pada Tahun Anggaran 2009 sebesar 53,89\%, Tahun Anggaran 2010 sebesar 58,31\%, dan Tahun Anggaran 2011 sebesar 69,37\%, serta tahun 2012 sebesar 76\%. Sementara itu, analisis belanja modal terhadap total belanja pada Tahun Anggaran 2009 sebesar 46,11\%, Tahun Anggaran 2010 sebesar 41,32\%, dan Tahun Anggaran 2011 sebesar 30,63\% serta tahun 2012 sebesar 23\%. Hal ini menunjukkan bahwa Pemerintah Kota Kotamobagu masih belum berorientasi pada belanja publik, karena setiap tahunnya belanja publik proporsinya menurun imbas dari ditingkatkannya belanja aparatur.

Untuk Pemerintah Kabupaten Bolaang Mongondow Timur, hasil analisis menunjukkan belanja operasi terhadap total belanja pada Tahun Anggaran 2009 sebesar 78\%, Tahun Anggaran 2010 sebesar 52\%, dan Tahun Anggaran 2011 sebesar 51\% serta tahun 2012 sebesar $64 \%$. Sementara itu, analisis belanja modal terhadap total belanja menunjukkan pada Tahun Anggaran 2009 sebesar 21,58\%, Tahun Anggaran 2010 sebesar 48,34\%, dan Tahun Anggaran 2011 sebesar 49,16\% serta tahun 2012 sebesar 35,6\%. Hal ini menunjukkan bahwa Pemerintah Kabupaten Bolaang Mongondow Timur masih belum berorientasi pada belanja publik, karena setiap tahunnya belanja publik proporsinya menurun imbas dari ditingkatkannya belanja aparatur, namun penurunan tersebut masih lebih besar dari Pemda Kota Kotamobagu.

\section{D.3. Rasio Efisiensi Belanja}

Dari hasil rasio efisiensi belanja tahun anggaran 2009-2012, dapat dilihat bahwa Pemerintah Kota Kotamobagu dapat melakukan efisiensi belanja, masing-masing pada Tahun Anggaran 2009 sebesar 8,74\%, Tahun Anggaran 2010 sebesar 11,73\%, dan Tahun Anggaran 2011 sebesar 14,04\%, untuk tahun 2012 sebesar 13,83\%. Hal ini menunjukkan bahwa setiap tahunnya terdapat peningkatan efisiensi yang cukup signifikan pada Pemerintah Kota Kotamobagu.

Untuk Pemerintah Kabupaten Bolaang Mongondow Timur diketahui dapat melakukan efisiensi belanja, masing-masing pada Tahun Anggaran 2009 sebesar 6,02\%, Tahun Anggaran 2010 sebesar 20,11\%, dan Tahun Anggaran 2011 sebesar 10,31\% untuk tahun 2012 sebesar 14,04\%. Hal ini menunjukkan Pemerintah Kabupaten Bolaang Mongondow Timur telah melakukan efisiensi yang cukup memadai.

\section{E. Kesimpulan}

Kedua pemerintah daerah sebagian besar varians belanjanya diatas 10\%. Artinya penyerapan anggaran di bawah $90 \%$, bisa jadi dinilai kurang baik. jika dilihat dari efisiensi anggaran yang ditunjukkan dari realisasi belanja dimana efisiensi yang dilakukan sebagian besar diatas $10 \%$, mengisyaratkan adanya kelemahan dalam perencanaan anggaran.

Keserasian belanja kedua pemerintah tersebut menunjukkan bahwa proporsi belanja operasi masih rendah, dan proporsi belanja modal sangat tinggi, yang berarti pemerintah daerah giat melakukan investasi modal jangka panjang untuk mencukupi asetnya. 


\section{Daftar Pustaka}

Allen, Richard dan Tommasi, Daniel, 2001. Managing a Public Expenditure: A Reference Book for Transition Coutries. OECD Paris.

Abdullah, H. 2004 Pengaruh Kejelasan Sasaran Anggaran, Pengendalian Akuntansi dan Sistem Pelaporan Terhadap Akuntabilitas Kinerja Instansi Pemerintah Pada Kabupaten dan Kota Di Daerah Istimewa Yogyakarta. Tesis. Program Pasca Sarjana UGM: Yogyakarta

Bastian, Indra., 2001, Akuntansi Sektor Publik di Indonesia, Edisi I, Penerbit : BPFE, Yogyakarta.

Bastian, Indra., 2006, Akuntansi Sektor Publik; Suatu Pengantar. Erlangga, Jakarta.

Mardiasmo. 2002.Akuntansi Sektor Publik. Penerbit Andi. Yogyakarta.

Mardiasmo. 2002. Otonomi dan Manajemen Keuangan Daerah. Andi. Yogyakarta Saragih

Peraturan Menteri Dalam Negeri nomor 13 tahun 2006 Tentang pedoman pengelolaan keuangan daerah.

Peraturan Pemerintah nomor 71 tahun 2010 Standar Akuntansi Pemerintah

Peraturan Pemerintah Republik Indonesia Nomor 58 Tahun 2005 tentang

Pengelolaan Keuangan Daerah

Undang-Undang Republik Indonesia Nomor 33 Tahun 2004 tentangPerimbangan Keuangan antara pemerintah pusat dan pemerintah daerah, Departemen Komunikasi dan Informatika. Jakarta

Sukriy, Abdullah \& Halim, Abdul. 2003. Pengaruh Dana Alokasi Umum (DAU) dan Pendapatan Asli Daerah (PAD) terhadap Belanja Pemerintah Daerah:Studi Kasus Kabupaten/Kota Di Jawa dan Bali. Simposium Nasional Akuntansi VI:1140-1159, Surabaya, 16-17 Oktober 2003 


\section{LAMPIRAN}

Tabel 1

Analisis Varians Belanja Pemerintah Kota Kotamobagu

\begin{tabular}{|c|c|c|c|c|c|}
\hline \multirow{2}{*}{ No. } & T.A. & Anggaran & Realisasi & \multicolumn{2}{c|}{ Selisih } \\
\cline { 3 - 6 } & & & & \multicolumn{2}{c|}{ Rp } \\
\hline 1 & 2009 & $313.604 .475 .610,00$ & $286.198 .421 .722,00$ & $27.406 .053 .888,00$ \\
\hline 2 & 2010 & $410.310 .001 .330,00$ & $362.179 .212 .167,00$ & $48.130 .789 .163,00$ & $11,73 \%$ \\
\hline 3 & 2011 & $442.797 .608 .917,00$ & $380.609 .742 .210,00$ & $62.187 .866 .707,00$ & $14,04 \%$ \\
\hline 4 & 2012 & $427.033 .631 .028,00$ & $367.995 .280 .953,00$ & $59.038 .350 .075,00$ \\
\hline
\end{tabular}

Tabel 2

Analisis Varians Belanja Pemerintah Kabupaten Bolaang Mongondow Timur

\begin{tabular}{|c|c|c|c|c|c|}
\hline No. & T.A. & Anggaran & Realisasi & \multicolumn{2}{|c|}{ Selisih } \\
\hline 1 & 2009 & $71.968 .435 .388,48$ & 67.638 .267 .103 .00 & $4.330 .168 .285,48$ \\
\hline 2 & 2010 & $299.287 .555 .577,22$ & $239.103 .971 .773,00$ & $60.183 .583 .804,22$ \\
\hline 3 & 2011 & $386.832 .314 .612,21$ & $346.966 .101 .273,00$ & $39.866 .213 .339,21$ \\
\hline 4 & 2012 & $331.152 .894 .183,97$ & $295.308 .486 .309,00$ & $10,30 \%$ \\
\hline
\end{tabular}

Tabel 3

Pertumbuhan Belanja Kota Kotamobagu TA 2009/2010

\begin{tabular}{|c|c|c|c|c|}
\hline \multirow[b]{2}{*}{ Uraian } & \multirow{2}{*}{$\begin{array}{l}\text { Realisasi Belanja } \\
\text { Tahun } 2009\end{array}$} & \multirow{2}{*}{$\begin{array}{l}\text { Realisasi Belanja } \\
\text { Tahun } 2010\end{array}$} & \multicolumn{2}{|c|}{ Pertumbuhan } \\
\hline & & & $\begin{array}{c}\text { Kenaikan } \\
\text { (Penurunan) }\end{array}$ & $\%$ \\
\hline \multicolumn{5}{|l|}{ BELANJA OPERASI } \\
\hline Belanja Pegawai & $111.237 .223 .627,00$ & $147.292 .506 .302,00$ & $36.055 .282 .675,00$ & $32,41 \%$ \\
\hline Belanja Barang & $39.249 .890 .730,00$ & $55.569 .062 .717,00$ & $16.319 .171 .987,00$ & $41,58 \%$ \\
\hline Hibah & $1.975 .000 .000,00$ & $4.017 .500 .000,00$ & $2.042 .500 .000,00$ & $103,42 \%$ \\
\hline Bantuan Sosial & $1.463 .510 .764,00$ & $3.932 .179 .900,00$ & $2.468 .669 .136,00$ & $168,68 \%$ \\
\hline Bantuan Keuangan & $300.000 .000,00$ & $375.000 .000,00$ & $75.000 .000,00$ & $25,00 \%$ \\
\hline \multicolumn{5}{|l|}{ BELANJA MODAL } \\
\hline Belanja Tanah & $4.425 .000 .000,00$ & $4.468 .457 .751,00$ & $43.457 .751,00$ & $0,98 \%$ \\
\hline Belanja Peralatan dan Mesin & $28.895 .960 .401,00$ & $19.552 .002 .115,00$ & $(9.343 .958 .286,00)$ & $-32,34 \%$ \\
\hline Belanja Gedung dan Bangunan & $27.349 .439 .052,00$ & $49.428 .976 .142,00$ & $22.079 .537 .090,00$ & $80,73 \%$ \\
\hline Belanja Jalan, Irigasi, dan Jaringan & $69.584 .335 .398,00$ & $73.309 .319 .490,00$ & $3.724 .984 .092,00$ & $5,35 \%$ \\
\hline Belanja Aset Tetap Lainnya & $1.718 .061 .750,00$ & $2.886 .032 .250,00$ & $1.167 .970 .500,00$ & $67,98 \%$ \\
\hline \multicolumn{5}{|l|}{ BELANJA TAK TERDUGA } \\
\hline Belanja Tak Terduga & - & $1.348 .175 .500,00$ & $1.348 .175 .500,00$ & \\
\hline JUMLAH BELANJA & 286.198.421.722,00 & 362.179.212.167,00 & $75.980 .790 .445,00$ & $26,55 \%$ \\
\hline
\end{tabular}

Tabel 4

Pertumbuhan Belanja Kota Kotamobagu TA 2010/2011

\begin{tabular}{|c|c|c|c|c|}
\hline \multirow[b]{2}{*}{ Uraian } & \multirow[b]{2}{*}{$\begin{array}{c}\text { Realisasi Belanja } \\
\text { Tahun } 2010\end{array}$} & \multirow[b]{2}{*}{$\begin{array}{l}\text { Realisasi Belanja } \\
\text { Tahun } 2011\end{array}$} & \multicolumn{2}{|c|}{ Pertumbuhan } \\
\hline & & & $\begin{array}{c}\text { Kenaikan } \\
\text { (Penurunan) }\end{array}$ & $\%$ \\
\hline \multicolumn{5}{|l|}{ BELANJA OPERASI } \\
\hline Belanja Pegawai & $147.292 .506 .302,00$ & $181.822 .367 .545,00$ & $34.529 .861 .243,00$ & $23,44 \%$ \\
\hline Belanja Barang & $55.569 .062 .717,00$ & $71.532 .901 .974,00$ & $15.963 .839 .257,00$ & $28,73 \%$ \\
\hline Hibah & $4.017 .500 .000,00$ & $5.823 .037 .500,00$ & $1.805 .537 .500,00$ & $44,94 \%$ \\
\hline Bantuan Sosial & $3.932 .179 .900,00$ & $3.242 .300 .000,00$ & $(689.879 .900,00)$ & $-17,54 \%$ \\
\hline Bantuan Keuangan & $375.000 .000,00$ & $1.609 .236 .100,00$ & $1.234 .236 .100,00$ & $329,13 \%$ \\
\hline \multicolumn{5}{|l|}{ BELANJA MODAL } \\
\hline Belanja Tanah & $4.468 .457 .751,00$ & $1.712 .800 .000,00$ & $(2.755 .657 .751,00)$ & $-61,67 \%$ \\
\hline Belanja Peralatan dan Mesin & $19.552 .002 .115,00$ & $28.699 .190 .877,00$ & $9.147 .188 .762,00$ & $46,78 \%$ \\
\hline Belanja Gedung dan Bangunan & $49.428 .976 .142,00$ & $28.004 .223 .157,00$ & $(21.424 .752 .985,00)$ & $-43,34 \%$ \\
\hline Belanja Jalan, Irigasi, dan Jaringan & $73.309 .319 .490,00$ & $55.280 .050 .157,00$ & $(18.029 .269 .333,00)$ & $-24,59 \%$ \\
\hline Belanja Aset Tetap Lainnya & $2.886 .032 .250,00$ & $2.883 .634 .900,00$ & $(2.397 .350,00)$ & $-0,08 \%$ \\
\hline \multicolumn{5}{|l|}{ BELANJA TAK TERDUGA } \\
\hline Belanja Tak Terduga & $1.348 .175 .500,00$ & - & $(1.348 .175 .500,00)$ & $-100,00 \%$ \\
\hline JUMLAH BELANJA & 362.179.212.167,00 & 380.609.742.210,00 & 18.430.530.043,00 & $5,09 \%$ \\
\hline
\end{tabular}


Tabel 5

\begin{tabular}{|c|c|c|c|c|}
\hline \multicolumn{5}{|c|}{ Pertumbuhan Belanja Kota Kotamobagu TA 2011/2012 } \\
\hline \multirow[b]{2}{*}{ Uraian } & \multirow{2}{*}{$\begin{array}{c}\text { Realisasi Belanja } \\
\text { Tahun } 2011\end{array}$} & \multirow{2}{*}{$\begin{array}{l}\text { Realisasi Belanja } \\
\text { Tahun } 2012\end{array}$} & \multicolumn{2}{|c|}{ Pertumbuhan } \\
\hline & & & $\begin{array}{c}\text { Kenaikan } \\
\text { (Penurunan) }\end{array}$ & $\%$ \\
\hline \multicolumn{5}{|l|}{ BELANJA OPERASI } \\
\hline Belanja Pegawai & $181.822 .367 .545,00$ & 204.890 .004 .954 .00 & 23.067 .637 .409 & $12,68 \%$ \\
\hline Belanja Barang & $71.532 .901 .974,00$ & $64.766 .334 .030,00$ & 6.766 .567 .944 & $28,73 \%$ \\
\hline Hibah & $5.823 .037 .500,00$ & $7.670 .000 .000,00$ & 1.846 .962 .500 & $31,71 \%$ \\
\hline Bantuan Sosial & $3.242 .300 .000,00$ & $1.343 .000 .000,00$ & $(1.339 .757 .700)$ & $-41,32 \%$ \\
\hline Bantuan Keuangan & $1.609 .236 .100,00$ & $1.634 .979 .900,00$ & 25.743 .800 & $1,59 \%$ \\
\hline \multicolumn{5}{|l|}{ BELANJA MODAL } \\
\hline Belanja Tanah & $1.712 .800 .000,00$ & $236.393 .500,00$ & $(1.476 .406 .500)$ & $-86,19 \%$ \\
\hline Belanja Peralatan dan Mesin & $28.699 .190 .877,00$ & 17.693.474.809.00 & $(11.005 .716 .068)$ & $-38,34 \%$ \\
\hline Belanja Gedung dan Bangunan & $28.004 .223 .157,00$ & $37.482 .160 .080,00$ & $(9.477 .936 .923)$ & $-33,84 \%$ \\
\hline Belanja Jalan, Irigasi, dan Jaringan & $55.280 .050 .157,00$ & $31.395 .545 .434,00$ & $(23.884 .504 .723)$ & $-43,20 \%$ \\
\hline Belanja Aset Tetap Lainnya & $2.883 .634 .900,00$ & $725.888 .246,00$ & $(2.157 .746 .654)$ & $-74,82 \%$ \\
\hline \multicolumn{5}{|l|}{ BELANJA TAK TERDUGA } \\
\hline Belanja Tak Terduga & - & $157.500 .000,00$ & $157.500 .000,00$ & $100,00 \%$ \\
\hline JUMLAH BELANJA & 380.609.742.210,00 & 367.995.280.953,00 & $(12.614 .461 .257,00)$ & $-3.31 \%$ \\
\hline
\end{tabular}

Tabel 6

Pertumbuhan Belanja Kabupaten Bolaang Mongondow Timur TA 2009/2010

\begin{tabular}{|c|c|c|c|c|}
\hline Uraian & Realisasi Belanja & Realisasi Belanja & \multicolumn{2}{|c|}{ Pertumbuhan } \\
\cline { 3 - 5 } & Tahun 2010 & $\begin{array}{c}\text { Kenaikan } \\
\text { (Penurunan) }\end{array}$ & \% \\
\hline BELANJA OPERASI & & & & \\
\hline Belanja Pegawai & $41.621538 .515,00$ & $76.887 .404 .248,00$ & $35,265,865,733.00$ & $84.73 \%$ \\
\hline Belanja Barang & $9.406 .947 .751,00$ & $38.963 .648 .660,00$ & $29,556,700,909.00$ & $314.20 \%$ \\
\hline Hibah & $415.000 .000,00$ & $5.547 .400 .000,00$ & $5,132,400,000.00$ & $1236.72 \%$ \\
\hline Bantuan Sosial & $678.875 .000,00$ & $1.482 .777 .880,00$ & $803,902,880.00$ & $118.42 \%$ \\
\hline Bantuan Keuangan & $808.750 .000,00$ & $579.352 .495,00$ & $(229,397,505.00)$ & $-28.36 \%$ \\
\hline BELANJA MODAL & & & & \\
\hline Belanja Tanah & $324.635 .476,00$ & $365.933 .575,00$ & $41,298,099.00$ & $12.72 \%$ \\
\hline Belanja Peralatan dan Mesin & $8.515 .163 .500,00$ & $21.894 .527 .051,00$ & $13,379,363,551.00$ & $157.12 \%$ \\
\hline Belanja Gedung dan Bangunan & 4.172 .674 .000 .00 & $22.699 .169 .824,00$ & $18,526,495,824.00$ & $444 . \%$ \\
\hline Belanja Jalan, Irigasi, dan Jaringan & $1.080 .517 .825,00$ & $69.544 .843 .815,00$ & $68,464,325,990.00$ & $6336.25 \%$ \\
\hline Belanja Aset Tetap Lainnya & $501.938 .000,00$ & $1.088 .914 .225,00$ & $586,976,225.00$ & $116.94 \%$ \\
\hline BELANJA TAK TERDUGA & & & & \\
\hline Belanja Tak Terduga & $112.200 .000,00$ & $50.000 .000,00$ & $(62,200,000.00)$ & $-55.44 \%$ \\
\hline JUMLAH BELANJA & $\mathbf{6 7 , 6 3 8 , 2 4 0 , 0 6 7 . 0 0}$ & $\mathbf{2 3 9 . 1 0 3 . 9 7 1 . 7 7 3 , 0 0}$ & $171,465,731,706.00$ & $253.50 \%$ \\
\hline
\end{tabular}

Tabel 7.

Pertumbuhan Belanja Kabupaten Bolaang Mongondow Timur TA 2010/2011

\begin{tabular}{|c|c|c|c|c|}
\hline \multirow[b]{2}{*}{ Uraian } & \multirow[b]{2}{*}{$\begin{array}{l}\text { Realisasi Belanja } \\
\text { Tahun } 2010\end{array}$} & \multirow[b]{2}{*}{$\begin{array}{l}\text { Realisasi Belanja } \\
\text { Tahun } 2011\end{array}$} & \multicolumn{2}{|c|}{ Pertumbuhan } \\
\hline & & & $\begin{array}{c}\text { Kenaikan } \\
\text { (Penurunan) }\end{array}$ & $\%$ \\
\hline \multicolumn{5}{|l|}{ BELANJA OPERASI } \\
\hline Belanja Pegawai & $76.887 .404 .248,00$ & $106.327 .916 .501,00$ & $29,440,512,253.00$ & $38.29 \%$ \\
\hline Belanja Barang & $38.963 .648 .660,00$ & $61.382 .106 .857,00$ & $22,418,458,197.00$ & $57.54 \%$ \\
\hline Hibah & $5.547 .400 .000,00$ & $1.781 .555 .500,00$ & $(3,765,844,500.00)$ & $-67.88 \%$ \\
\hline Bantuan Sosial & $1.482 .777 .880,00$ & $3.100 .700 .000,00$ & $1,617,922,120.00$ & $109.11 \%$ \\
\hline Bantuan Keuangan & $579.352 .495,00$ & $3.394 .362 .226,00$ & $2,815,009,731.00$ & $485.89 \%$ \\
\hline \multicolumn{5}{|l|}{ BELANJA MODAL } \\
\hline Belanja Tanah & $365.933 .575,00$ & $970.250 .800,00$ & $604,317,225.00$ & $165.14 \%$ \\
\hline Belanja Peralatan dan Mesin & $21.894 .527 .051,00$ & $37.181 .003 .922,00$ & $15,286,476,871.00$ & $69.82 \%$ \\
\hline Belanja Gedung dan Bangunan & $22.699 .169 .824,00$ & $50.389 .847 .115,00$ & $27,690,677,291.00$ & $121.99 \%$ \\
\hline Belanja Jalan, Irigasi, dan Jaringan & $69.544 .843 .815,00$ & $81.877 .796 .412,00$ & $12,332,952,597.00$ & $17.73 \%$ \\
\hline Belanja Aset Tetap Lainnya & $1.088 .914 .225,00$ & $134.783 .350,00$ & $(954,130,875.00)$ & $-87.62 \%$ \\
\hline \multicolumn{5}{|l|}{ BELANJA TAK TERDUGA } \\
\hline Belanja Tak Terduga & $50.000 .000,00$ & $425.778 .590,00$ & $375,778,590.00$ & $751.56 \%$ \\
\hline JUMLAH BELANJA & 239.103.971.773,00 & $346.966 .101 .273,00$ & $107,862,129,500.00$ & $45.11 \%$ \\
\hline
\end{tabular}


Tabel 8

Pertumbuhan Belanja Kabupaten Bolaang Mongondow Timur TA 2011/2012

\begin{tabular}{|c|c|c|c|c|}
\hline Uraian & Realisasi Belanja & Realisasi Belanja & \multicolumn{2}{|c|}{ Pertumbuhan } \\
\cline { 4 - 5 } & Tahun 2012 & Kenaikan & (Penurunan) & \% \\
\hline BELANJA OPERASI & & & & \\
\hline Belanja Pegawai & $106.327 .916 .501,00$ & $120.254 .367 .590,00$ & $13,926,451,089.00$ & $13.10 \%$ \\
\hline Belanja Barang & $61.382 .106 .857,00$ & $57.459 .228 .224,00$ & $(3,922,878,633.00)$ & $-6.39 \%$ \\
\hline Hibah & $1.781 .555 .500,00$ & $2.349 .000 .000,00$ & $567,444,500.00$ & $31.85 \%$ \\
\hline Bantuan Sosial & $3.100 .700 .000,00$ & $327.000 .000,00$ & $(2,773,700,000.00)$ & $-89.45 \%$ \\
\hline Bantuan Keuangan & $3.394 .362 .226,00$ & $8.886 .496 .600,00$ & $5,492,134,374.00$ & $161.80 \%$ \\
\hline BELANJA MODAL & & & & \\
\hline Belanja Tanah & $970.250 .800,00$ & $1.919 .937 .500,00$ & $949,686,700.00$ & $97.88 \%$ \\
\hline Belanja Peralatan dan Mesin & $37.181 .003 .922,00$ & $12.934 .137 .326,00$ & $(24,246,866,596.00)$ & $-65.21 \%$ \\
\hline Belanja Gedung dan Bangunan & $50.389 .847 .115,00$ & $36.540 .850 .633,00$ & $(13,848,996,482.00)$ & $-27.48 \%$ \\
\hline Belanja Jalan, Irigasi, dan Jaringan & $81.877 .796 .412,00$ & $49.707 .335 .236,00$ & $(32,170,461,176.00)$ & $-39.29 \%$ \\
\hline Belanja Aset Tetap Lainnya & $134.783 .350,00$ & $3.995 .918 .150,00$ & $3,861,134,800.00$ & $2864.70 \%$ \\
\hline BELANJA TAK TERDUGA & & & & \\
\hline Belanja Tak Terduga & $425.778 .590,00$ & $44.388 .013 .435,46$ & $43,962,234,845.00$ & $10325.14 \%$ \\
\hline JUMLAH BELANJA & $\mathbf{3 4 6 . 9 6 6 . 1 0 1 . 2 7 3 , 0 0}$ & $\mathbf{2 9 5 . 3 0 8 . 4 8 6 . 3 0 9 , 0 0}$ & $(51,657,614,964.00)$ & $-14.89 \%$ \\
\hline
\end{tabular}

Tabel 9

Analisis Belanja Operasi Terhadap Total Belanja Kota Kotamobagu

\begin{tabular}{|c|c|c|c|}
\hline T.A. & Total Belanja Operasi $(\mathbf{R p )}$ & Total Belanja $(\mathbf{R p )}$ & Rasio Belanja Operasi terhadap Total Belanja (\%) \\
\hline 2009 & $154.225 .625 .121,00$ & $286.198 .421 .722,00$ & $53,89 \%$ \\
\hline 2010 & $211.186 .248 .919,00$ & $362.179 .212 .167,00$ & $58,31 \%$ \\
\hline 2011 & $264.029 .843 .119,00$ & $380.609 .742 .210,00$ & $69,37 \%$ \\
\hline 2012 & $280.304 .318 .884,00$ & $367.995 .280 .953,00$ & $76 \%$ \\
\hline
\end{tabular}

Tabel 10

Analisis Belanja Operasi Terhadap Total Belanja Kabupaten Bolaang Mongondow Timur

\begin{tabular}{|l|c|c|c|}
\hline \multirow{2}{*}{ T.A. } & Total Belanja Operasi (Rp) & Total Belanja (Rp) & Rasio Belanja Operasi terhadap Total Belanja (\%) \\
\hline 2009 & $52.931 .138 .302,00$ & $67.638 .267 .103,00$ & $78 \%$ \\
\hline 2010 & $123.460 .583 .283,00$ & $239.103 .971 .773,00$ & $52 \%$ \\
\hline 2011 & $175.986 .641 .084,00$ & $346.966 .101 .273,00$ & $51 \%$ \\
\hline 2012 & $189.276 .092 .414,00$ & $295.308 .486 .309,00$ & $64 \%$ \\
\hline
\end{tabular}

Tabel 11

Analisis Belanja Modal Terhadap Total Belanja Kota Kotamobagu

\begin{tabular}{|c|c|c|c|}
\hline T.A. & Total Belanja Modal (Rp) & Total Belanja (Rp) & Rasio Belanja Modal terhadap Total Belanja (\%) \\
\hline 2009 & $131.972 .796 .601,00$ & $286.198 .421 .722,00$ & $46,11 \%$ \\
\hline 2010 & $149.644 .787 .748,00$ & $362.179 .212 .167,00$ & $41,32 \%$ \\
\hline 2011 & $116.579 .899 .091,00$ & $380.609 .742 .210,00$ & $30,63 \%$ \\
\hline 2012 & $87.533 .462 .069,00$ & $367.995 .280 .953,00$ & $23,79 \%$ \\
\hline
\end{tabular}


Tabel 12

Analisis Belanja Modal Terhadap Total Belanja Kabupaten Bolaang Mongondow Timur

\begin{tabular}{|l|c|c|c|}
\hline \multirow{2}{*}{ T.A. } & Total Belanja Modal (Rp) & Total Belanja (Rp) & Rasio Belanja Modal terhadap Total Belanja (\%) \\
\hline 2009 & $14.594 .928 .801,00$ & $67.638 .267 .103,00$ & \\
\hline 2010 & $115.593 .388 .490,00$ & $239.103 .971 .773,00$ & $48.58 \%$ \\
\hline 2011 & $170.553 .681 .599,00$ & $346.966 .101 .273,00$ & $49.16 \%$ \\
\hline 2012 & $105.098 .178 .845,00$ & $295.308 .486 .309,00$ & $35,6 \%$ \\
\hline
\end{tabular}

Tabel 13

Rasio Efisiensi Belanja Kota Kotamobagu

\begin{tabular}{|c|c|c|c|}
\hline T.A. & Anggaran Belanja (Rp) & Realisasi Belanja (Rp) & Rasio Efisiensi Belanja (\%) \\
\hline 2009 & $313.604 .475 .610,00$ & $286.198 .421 .722,00$ & $91,26 \%$ \\
\hline 2010 & $410.310 .001 .330,00$ & $362.179 .212 .167,00$ & $88,27 \%$ \\
\hline 2011 & $442.797 .608 .917,00$ & $380.609 .742 .210,00$ & $85,96 \%$ \\
\hline 2012 & $427.033 .631 .028,00$ & $367.995 .280 .953,00$ & $86,17 \%$ \\
\hline
\end{tabular}

Tabel 14

Rasio Efisiensi Belanja Kabupaten Bolaang Mongondow Timur

\begin{tabular}{|c|c|c|c|}
\hline T.A. & Anggaran Belanja (Rp) & Realisasi Belanja (Rp) & $\begin{array}{c}\text { Rasio Efisiensi } \\
\text { Belanja (\%) }\end{array}$ \\
\hline 2009 & $71.968 .435 .388,48$ & 67.638 .267 .103 & 93.98 \\
\hline 2010 & $299.287 .555 .577,22$ & $239.103 .971 .773,00$ & 79.89 \\
\hline 2011 & $386.832 .314 .612,21$ & $346.966 .101 .273,00$ & 89.69 \\
\hline 2012 & $331.152 .894 .183,97$ & $295.308 .486 .309,00$ & $89,18 \%$ \\
\hline
\end{tabular}

